\title{
Toward a more expansive understanding of food hubs
}

\author{
Megan Horst, ${ }^{\mathrm{a},}{ }^{*}$ Eva Ringstrom, ${ }^{\mathrm{b}}$ Shannon Tyman, ${ }^{\mathrm{c}}$ Michael K. Ward, ${ }^{\mathrm{d}}$ Virginia Werner, ${ }^{\mathrm{e}}$ Branden Born ${ }^{\mathrm{f}}$
}

Submitted 4 May 2011 / Accepted 2 August 2011 / Published online 21 December 2011

Citation: Horst, M., Ringstrom, E., Tyman, S., Ward, M. K., Werner, V., \& Born, B. (2011). Toward a more expansive

understanding of food hubs. Journal of Agriculture, Food Systems, and Community Development, 2(1), 209-225.

http://dx.doi.org/10.5304/jafscd.2011.021.017

Copyright (C) 2011 by New Leaf Associates, Inc.

\begin{abstract}
A review of the uses of the term "food hub" reveals a dynamic and evolving concept. Since planners need to understand these various uses, we offer a preliminary framework for a food hub

a PhD student, University of Washington, Dept. of Urban Design \& Planning, Seattle, WA USA

b MPA/MUP candidate, University of Washington, Evans School of Public Affairs \& Urban Design and Planning, Seattle, WA USA

c PhD student, University of Washington, College of Built Environments, Seattle, WA USA

d MUP candidate, University of Washington, Dept. of Urban Design and Planning, Seattle, WA USA

e MUP/MLA candidate, University of Washington, Urban Design and Planning \& Landscape Architecture, Seattle, WA USA

${ }^{\mathrm{f}}$ Associate professor, University of Washington, Department of Urban Design and Planning College of Built Environments, Seattle, WA USA

* Corresponding author: Megan Horst, 2008 10th Avenue E, Seattle, WA 98102 USA; +1-414-350-6093; horstm@uw.edu
\end{abstract}

typology. We also suggest attributes and a definition that should be considered when assessing existing sites and planning for new food hubs. We then assess three food hub sites in Seattle, Washington, using our typology and characteristics that should be considered (audience, ownership, purpose, design and siting, and scale). Our assessment demonstrates that the strengths, viability, and vitality of each food hub are derived from attributes not currently considered by the most commonly used, type-focused definitions of food hubs. Our contribution adds clarity to the evolving discussion about food hubs, and describes elements for communities, particularly the planning community, to consider when planning for them.

\section{Keywords}

agglomeration, agricultural urbanism, distribution, food hub, food system, food value chain, market, planning

\section{The Rise of the Food Hub Concept}

Many initiatives such as community supported agriculture and farmers' markets exist as alterna- 
tives to the conventional, industrialized, global food system (Kloppenberg, Lezberg, Master, \& Stevenson, 2000). These initiatives expand infrastructure and market opportunities for "agriculture of the middle" and promote a more sustainable food system and food value chains (Connel, Smithers, \& Joseph, 2008). One concept rapidly gaining recognition and attention across a diverse group of stakeholders - from nonprofit organizations and urban designers to universities and the United States Department of Agriculture - is the food hub. In a preliminary survey, the United States Department of Agriculture (USDA) has identified over 100 operational food hubs around the country, with average annual sales of nearly US $\$ 1$ million and an average of 13 jobs created per food hub, indicating the growing presence and impact of food hubs across the nation (USDA AMS, 2011). With the food hub concept growing in application, it is becoming important to establish a practicable definition. By reviewing existing approaches to defining food hubs and building typologies, we add clarity to the evolving discussion about food hubs. We also describe elements for communities, particularly the urban planning community, to consider when planning for food hubs.

Food hubs appear to offer numerous benefits, including expanded market opportunities for farmers, job creation, and increased access to healthy foods by consumers (National Good Food Network, 2011). They have the potential to improve the economic viability of small to medium-scale farms by creating networking opportunities, year-round markets, and aggregated processing and wholesale facilities that help increase economies of scale. A food hub focused on aggregation and distribution allows multiple producers to combine their products and ship them to wholesale purchasers in greater volume than most individual producers could manage on their own. A retail-oriented food hub that brings together multiple producers becomes a denser retail site or potentially a year-round farmers' market. In cities, food hubs increase the presence of locally produced food, which serves to educate consumers about their food sources, local farmers, and food processors. Food hubs increase access to healthy food for particular groups of residents. They also serve as nodes for social interaction. By having a more clear understanding of the full range of food hubs' possible functions, urban planners and other stakeholders are better equipped to evaluate and support existing food hubs, as well as to plan for the development of new ones.

\section{Would You Know a Food Hub If You Saw One? Definitions and Concepts}

The term "food hub" is used in multiple ways across diverse communities. This variation reveals a dynamic and evolving concept whose substantive characteristics are prioritized differently according to circumstances and the practitioners' disciplines. As a new term, its meaning is not widely known or shared. For example, in Everett, Washington, an urban planner and local farmers' cooperative have been working to establish a permanent agglomeration facility with processing infrastructure and direct sales outlets. Until asked, though, one of the project's main coordinators had never identified the project as a "food hub" (L. Neunzig, personal communication, February 2011). Although the project was never identified as a food hub during the planning stages, it may have benefitted from the resources and experiences of professionals and grassroots organizers familiar with the concept.

Morley, Morgan, and Morgan (2008) anticipated the wide array of definitions currently used. They highlight the importance of establishing a clear notion of what food hubs represent and how they can be developed. The authors note that food hubs can contribute narrowly to increasing market efficiency, or can offer a broader vision that encompasses a healthy food system and diversified food culture. Short of offering a definition, the authors state, "On the simplest level the Food Hub can represent any kind of organizational model where food sourcing and supply is coordinated, and may be contrasted with a wholly dispersed market system (becoming more credible through internet shopping) comprising of [sic] direct links between the producer and the consumer" (p. 3). 
As noted by Morley et al., there is a range of conceptions about food hubs. In North America, definitions of food hubs come from one of three frameworks: the USDA, the nonprofit organization Wholesome Wave, and landscape designers and authors Janine de la Salle and Mark Holland in their book Agricultural Urbanism: Handbook for Building Sustainable Food Systems in $21^{\text {st }}$ Century Cities. The USDA, Wholesome Wave, and de la Salle and Holland embrace different conceptions of the food hub, with different foci and functions, leading to a term imbued with inherent complexity. Adapting the deconstructive approach used to describe the complexity of neighborhoods by Kallus and LawYone (2000), we describe these three approaches as instrumental (producer-oriented), humanistic (people-oriented), and phenomenological (community-oriented). In addition, we identify the key components of each food hub definition as well as its strengths and weaknesses.

The approach used by the USDA to define food hubs (unofficially) follows an instrumental and economic development perspective. It is largely producer-centric. According to their working definition, a food hub is "a centrally located facility with a business management system that facilitates the aggregation, storage, processing, distribution and/or marketing of locally or regionally produced food products" (2011). This definition is widely accepted and used with close variations by organizations such as the National Good Food Network (2011) and research institutions like the Occidental College Urban and Environmental Policy Institute (n.d.). The Regional Food Hub Advisory Council (2010) concluded that food aggregation and wholesale distribution are the two most critical elements of food hubs. The council also noted that "because of the great diversity among emerging Regional Food Hub (RFH) projects and the desire to include of all of these efforts in a strategy for food systems reform, the description is less prescriptive than many" (p. 3). The Regional Food Hub Advisory Council's exact definition of a food hub is "an integrated food distribution system that coordinates agricultural production and the aggregation, storage, processing, distribution, and marketing of locally or regionally produced food products" (2010, p. 3). The USDA identifies the core components of a food hub as aggregation and distribution opportunities for wholesale products (including drop-off and pick-up points), the active coordination of activities along the food supply chain, and the provision of permanent facilities such as space and equipment for processing, packaging, storing, freezing, and other food-related activities. Other key attributes of the USDA's concept of a regional food hub include an emphasis on aggregating products from local small and midsized producers and providing these source-identified locally grown products to wholesale buyers. They also include producer-oriented services such as post-harvest handling, packaging, branding, and labeling. Other potential features include wholesale and retail opportunities, health and social services, community kitchens, community meeting spaces, and educational programming. The USDA does not consider this definition to be official and the agency is working with partners to refine the definition (USDA, 2011).

A second approach to food hubs takes a more humanistic perspective, and is more community and health-centric rather than producer-focused. The Connecticut nonprofit organization Wholesome Wave discusses food hubs under the heading "Healthy Food Commerce Initiative," indicating an emphasis on health (n.d.). While their definition of a food hub is based on the USDA's definition (Wholesome Wave, n.d.), they also provide an image of a food hub that shows the intersection among a value-added food processing facility, storage and distribution system, and community-owned food market (Wholesome Wave, 2010). The emphasis on the communityowned food market, akin to a combination of a grocery store, food coop and farmers' market, highlights the role of the broader community and defines specific elements of food retail to be included in a food hub. This vision of a food hub expands the possibilities for ownership by consumers, rather than producers. Wholesome Wave also notes other important elements of a food hub, including a community shared kitchen, administration (including a management office and 
education classroom) and general support (utility, vertical circulation, and parking). The prime function of a food hub is to "provide easy access, opportunity, and viability for small producers and low-income consumers" and the main purpose is to "contribute to a healthier, more vibrant, and equitable system" (Wholesome Wave, n.d.).

A third approach to food hubs - the perspective set forth in Agricultural Urbanism (2010) by Janine de la Salle and Mark Holland of the Canadian design firm HB Lanarc - stems from a phenomenological and community-centric approach that highlights the experience of people within the food hub's physical environment. Here, the intent is to assist urban designers in considering and developing food hubs and the experiences they offer. De la Salle and Holland define a food hub as a "place that brings together a wide spectrum of land uses, design strategies, and programs focused on food in order to increase access, visibility, and the experience of sustainable urban and regional food systems within a city" (p. 150). They situate their definition within a greater vision of what they call agricultural urbanism: "a planning, policy, and design framework for developing a wide range of sustainable food and agricultural elements into multiple community scales. A[gricultural] U[rbanism] focuses on integrating the widest possible range of food system elements into a community in a manner appropriate to the community" (p. 9). More than the preceding food hub definitions, this definition highlights urban design elements and focuses on the sensory experience of the food hub visitor. It also includes aspects of the instrumental and humanistic

Table 1. Summary of Three Common Food Hub Definitions

\begin{tabular}{|c|c|c|c|c|}
\hline Source & Definition & $\begin{array}{l}\text { Major Components and } \\
\text { Elements }\end{array}$ & Function & Purpose \\
\hline $\begin{array}{l}\text { United States } \\
\text { Department of } \\
\text { Agriculture } \\
\text { (working definition; } \\
\text { not official) }\end{array}$ & $\begin{array}{l}\text { A centrally located facility } \\
\text { with a business manage- } \\
\text { ment system that facili- } \\
\text { tates the aggregation, } \\
\text { storage, processing, } \\
\text { distribution and/or } \\
\text { marketing of locally or } \\
\text { regionally produced food } \\
\text { products. }\end{array}$ & $\begin{array}{l}\text { 1. Aggregation and distribu- } \\
\text { tion of wholesale products } \\
\text { 2. Active coordination of } \\
\text { activities along the food } \\
\text { supply chain } \\
\text { 3. Provision of permanent } \\
\text { facilities for storage, } \\
\text { packaging, processing, } \\
\text { and sale }\end{array}$ & $\begin{array}{l}\text { Aggregation and } \\
\text { distribution of } \\
\text { locally produced } \\
\text { foods }\end{array}$ & $\begin{array}{l}\text { Increase small and } \\
\text { midsized } \\
\text { producers' access } \\
\text { to wholesale } \\
\text { market channels }\end{array}$ \\
\hline Wholesome Wave & $\begin{array}{l}\text { Same as USDA (above), } \\
\text { though with an expanded } \\
\text { emphasis on the role of a } \\
\text { community owned food } \\
\text { market. }\end{array}$ & $\begin{array}{l}\text { 1. Value-added food } \\
\text { processing facility } \\
\text { 2. Storage and distribution } \\
\text { system } \\
\text { 3. Community-owned food } \\
\text { market } \\
\text { 4. Community shared kitchen } \\
\text { 5. Administrative (including } \\
\text { education) } \\
\text { 6. General support }\end{array}$ & $\begin{array}{l}\text { Provide easy } \\
\text { access, } \\
\text { opportunity, and } \\
\text { viability for small } \\
\text { producers and } \\
\text { low-income } \\
\text { consumers }\end{array}$ & $\begin{array}{l}\text { Contribute to a } \\
\text { healthier, more } \\
\text { vibrant, and } \\
\text { equitable system }\end{array}$ \\
\hline $\begin{array}{l}\text { Agricultural } \\
\text { Urbanism, } \\
\text { de la Salle and } \\
\text { Holland }\end{array}$ & $\begin{array}{l}\text { A place that brings } \\
\text { together a wide spectrum } \\
\text { of land uses, design } \\
\text { strategies, and programs } \\
\text { focused on food to } \\
\text { increase access, visibility, } \\
\text { and the experience of } \\
\text { sustainable urban and } \\
\text { regional food systems } \\
\text { within a city. }\end{array}$ & $\begin{array}{l}\text { 1. Diversity of food and } \\
\text { beverage retail and } \\
\text { wholesale } \\
\text { 2. Processing and storage } \\
\text { of food and beverages } \\
\text { 3. Institutions and educa- } \\
\text { tional opportunities } \\
\text { 4. Architectural and } \\
\text { landscape design } \\
\text { 5. Diverse programming }\end{array}$ & $\begin{array}{l}\text { Place-based, } \\
\text { promotion of food } \\
\text { experience }\end{array}$ & $\begin{array}{l}\text { Enhance the } \\
\text { visibility and } \\
\text { experience of local } \\
\text { food systems } \\
\text { within a city; } \\
\text { connect food } \\
\text { access to land use } \\
\text { and design }\end{array}$ \\
\hline
\end{tabular}


approaches, including a focus on retail, wholesale, and processing, as well as on education and programming. De la Salle and Holland identify the key elements of a food hub as a diversity of wholesale and retail, processing, education and institutions, design, and programming.

These three definitions, along with the key elements, functions, and purposes, are summarized in table 1 . These definitions are intentionally limiting. Limiting the scope of what a food hub is, and is not, helps organizations such as the USDA gain clarity about the challenges and opportunities facing the development of robust local and regional food systems. Accordingly, in exploring the potential for food hubs it is important to recognize and understand the limits imposed by particular definitions.

The USDA working definition emphasizes agglomeration and wholesale with little to no discussion of a retail or social component. This approach is well suited for certain kinds of enterprises, particularly regional distribution centers focused on serving the aggregation needs of farmers. However, the focus on business management systems and agglomeration activities ignores types of food hubs that do not operate from that kind of business-driven model.

The Wholesome Wave definition focuses on health and community. Its description emphasizes the participation by the broader community, particularly through a community-owned food market, community kitchen, and education. It also emphasizes the role of food hubs in improving access, opportunity, and viability for small producers and low-income consumers. On the other hand, the Wholesome Wave definition lacks an emphasis on the food hub's connections to other parts of the food system, including production, processing, waste management, and recycling.

Finally, de la Salle and Holland's food hub definition highlights the role of educational institutions and programming, as well as that of siting, design, and other place-based characteristics. Yet their definition falls short of making the explicit connec- tions to the infrastructure needed to support local producers and strengthen the local food system. It also does not emphasize access by diverse populations.

\section{Highlighting the Sustainable Food System}

Recognizing the limits of these focused definitions, we suggest that Kloppenberg et al.'s (2000) proposed list of sustainable food system attributes serves as a useful platform for creating a fuller understanding of the food hub phenomenon. The 14 attributes of a sustainable food system identified by Kloppenberg are:

1. ecologically sustainable

2. knowledgeable/communicative

3. proximate

4. economically sustaining

5. participatory

6. sustainably regulated

7. just/ethical

8. $\quad$ sacred

9. healthy

10. diverse

11. relational

12. culturally nourishing

13. seasonal/temporal

14. value-oriented (associative) economies

Several of these attributes directly encompass those identified by the USDA, Wholesome Wave, and de la Salle and Holland. For example, the attributes of "economically sustaining" and "value-oriented economies" speak to the role highlighted by the USDA of food hubs in supporting individually owned small and medium-sized farms and businesses through the provision of affordable aggregation, processing, and distribution infrastructure. Likewise, the "knowledgeable/ communicative" and "participatory" attributes encompass and extend the concept of healthrelated services emphasized by Wholesome Wave and the programming and education highlighted by de la Salle and Holland. Kloppenberg's list also draws attention to possibilities for food hubs by including attributes not found in the three definitions discussed above, such as "sacred" and "culturally nourishing," although these terms may 
be difficult to operationalize in practice. Kloppenberg's list provides a starting point for establishing a more comprehensive definition of food hubs.

\section{A New Typology of Food Hubs}

We propose a typology that illustrates the broader range of forms that food hubs can take and the roles they can play. This typology builds on the list of existing food hub models outlined by the USDA, and a number of the examples listed are highlighted by the agency (2011). Other examples are from the Northwest, as the authors are more familiar with that region. This typology contributes to a better collective understanding of food hubs. In addition to addressing ownership, as was done by the USDA, our typology discusses other critical considerations, including purpose, design, and scale. The examples provided are illustrative and highlight the diversity of food hub types.

\section{Boutique/Ethnic/Artisanal Food Hub: Often} operates in one facility under single ownership, with a focus on artisanal, craft, and specialty food and beverage sales. Markets local produce, dairy, meat, and grains. Demonstrates strong and visible connections to local farmers and producers. May include a focus on particular ethnic and cultural foods.

Example: Melrose Market, Seattle, Washington. Melrose Market opened in 2010 and occupies two refurbished historic buildings in a dense downtown neighborhood. The small facility is owned by two developers who lease space to seven specialty food retail businesses and restaurants. The facility caters to affluent shoppers, and most of the stores feature local and artisanal foods. Some offer educational opportunities and food and wine tastings, and are transparent about their food choices. For example, the website of Homegrown, a sandwich shop, states that "Our goal at Homegrown is not only to create sandwiches out of sustainable ingredients but also to make sandwich creation sustainable itself....We consider our environmental impact for every ingredient choice, often between two competing theories: eating organic and eating local. We take the best from both worlds to create our sus- tainable sandwiches. We like to call this sandwich environmentalism" (Homegrown, n.d., "Theory"). The Melrose Market businesses have a common atrium, offering a gathering place for customers and employees. Meanwhile, store owners have built mutually beneficial relationships, as noted in our conversations with them. For example, the market's restaurant features cheese and meat sourced from two other retailers in the building. In conversation, two store owners expressed their appreciation of the support and shared sense of purpose provided by the food hub-type setting.

Consumer-Cooperative Model: This type of food hub is initiated by an association of consumers who purchase in wholesale quantities from local producers for packing and redistribution to individuals.

Example: Puget Consumers Co-op Natural Markets, based in Seattle, W ashington. Initiated in 1953, the Puget Consumers Co-op, known as PCC, is owned and operated by over 45,000 members, making it the largest consumer model in the United States (PCC Natural Markets, n.d.). There are nine retail outlets throughout the region at which both members and nonmembers can shop. PCC actively partners with local organic farmers to purchase produce, meat, poultry, dairy, and specialty goods, although products offered at the stores are globally sourced. As part of its efforts to support local farmers, PCC also supports a nonprofit land trust dedicated to preserving local farmland and transitioning it into organic production. In addition, PCC focuses on providing food-based education through activities such as cooking classes, podcasts, herb walks, and publications including newsletters and email digests.

Destination Food Hub: This is a large-scale facility or set of facilities where food-related retail businesses serve as a primary attraction for both local residents and tourists, and tourists make up a significant percentage of customers.

Example: Pike Place Market, Seattle, Washington. Pike Place Market is Seattle's most iconic and wellknown public market. The nine-acre (4 hectare) 
market is located in the heart of downtown and is operated by Pike Place Market Preservation and Development Authority, a nonprofit, public corporation chartered by the city of Seattle. Its founding law, the Market Charter, requires it to "preserve, rehabilitate, and protect the Market's buildings; increase opportunities for farm and food retailing in the Market; incubate and support small and marginal businesses; and provide services for low-income people" (Pike Place Market Preservation Authority, 2003). It is home to more than 200 year-round commercial businesses (many of them food-related), 200 craftspeople, and approximately 100 farmers who rent table space by the day. In addition to a wide variety of raw food retail, there are processors (primarily cheese and beer making), vendors of value-added products (nuts, jams, dried fruit), and restaurants. The market attracts tourists as well as locals, totaling around 10 million visitors per year. There are educational offerings and programs throughout the year, ranging from a cheese festival to chef demonstrations. There is also a variety of services for low-income people, including subsidized housing, a health clinic, senior center, food bank, child care and preschool, and community kitchen. The market's design includes elements that distinguish it from surrounding areas, not the least of which are the historic "Public Market Center" and "Meet the Producers" signs. Historic preservation and approval of new design features are overseen by the Market Historical Commission, which has a mandate to preserve the market's physical and social character.

\section{Education and Human Service-Focused Food}

Hub: This type of hub enables food-related community services such as community gathering places, community kitchens and processing facilities, SNAP and WIC benefit sign-up, agricultural skills training, healthy cooking and eating classes and demonstrations, and community garden and agricultural microenterprise project planning. Often includes demonstration and learning gardens. Access for low-income people is prioritized.

Example: Growing Power, Milwankee, Wisconsin. Growing Power is a national nonprofit organization and land trust supporting people from diverse backgrounds, and the environments in which they live, by helping to provide equal access to healthy, high-quality, safe and affordable food for people in all communities (Growing Power, n.d.). Growing Power's prototype for a Community Food Center is a historic two-acre (0.8-hectare) farm and greenhouse operation in Milwaukee. The center hosts hands-on activities; large-scale demonstration projects, and growing space for some 20,000 plants, vegetables, and herbs; aquaculture; and a livestock inventory of chickens, goats, ducks, rabbits, and bees. There is also a retail store that sells produce, meat, worm castings, and compost to the community. The center offers schools, universities, government agencies, farmers, activists, and community members opportunities to learn from and participate in the development and operation of community food systems.

Neighborhood-Based Food Hub ${ }^{1}$ : This hub type is defined by multiple contiguous city blocks with a high concentration of independent wholesale and retail food outlets. This district-style food hub provides access to diverse and healthy food options for local residents of varying income levels.

Example: Chinatown-International District, Seattle, Washington. The Chinatown-International District is a federally recognized historic district and a mixeduse urban neighborhood. Information was obtained from Internet sources including Google Maps and individual retailer websites, along with site visits. The district encompasses over 130 independent food establishments. These include over 85 restaurants; 16 bakeries, tea houses, and coffee shops; 12 grocers; three seafood markets; four wholesale outlets; and manufacturers selling poultry, soy products, noodles, and fortune cookies. There is also a culturally important community garden. The neighborhood serves as the cultural hub for Asian Americans in the area. The neighborhood's food establishments and festivals, such as Lunar New Year, attract people

\footnotetext{
${ }^{1}$ This typology could also be called a "food precinct" or "food district." Food precinct is a term used by de la Salle and Holland. The term "food district" comes from literature on economic clustering.
} 
living in the neighborhood, members of the greater Asian community, businesspeople, Seattle-area residents, and out-of-town visitors. There are many educational opportunities, including an assortment of classes, ranging from tea tastings at a tea house to Japanese Gardeners Association panels at a museum to teen cooking classes at a community center to "food tours" of the district. The Chinatown-International District exhibits many food hub characteristics, even though it was not intentionally developed around a specific food-related identity like many newer food hubs, nor is it internally identified as one.

Online Food Hub Network: This virtual food hub is an Internet-based online directory and marketplace that fosters efficient connections between local and regional food producers and consumers, including institutions, restaurants, and stores. It may have a physical location, but this is not necessary.

Example: Puget Sound Food Network, Washington State. The mission of the Puget Sound Food Network is to increase the production, distribution, and consumption of regionally produced food (Puget Sound Food Network, n.d.). Using a web-based platform, the network enables real-time communication and facilitates online food-related transactions between food producers, consumers, and other participants in the Puget Sound regional food system. Created and managed by the nonprofit Northwest Agriculture Business Center, the Puget Sound Food Network project enables farmers and other food producers to communicate conveniently and directly with buyers, locate processing, distribution, and storage facilities in the Puget Sound area, coordinate with other regional producers with complementary needs (for such items as bottles, boxes, and farm supplies), and consolidate products with other producers to meet growing consumer demand and potential delivery requirements.

Regional Aggregation Food Hub: This type includes a centrally located facility with a business management system that coordinates the aggregation, storage, processing, distribution and/or marketing of locally or regionally produced food products. The facility is often actively managed and coordinated by one organization. Specific examples of regional aggregation food hubs include packing facilities, where fresh horticultural products are cooled, graded, packaged, and marketed to larger wholesale distribution centers and/or retail grocers. Wholesale terminals are another example. Wholesalers receive large quantities of fresh produce by rail, truck, and air from local sources and around the world for sale and distribution to grocers, restaurants, institutions, and other businesses.

\section{Example: Hunts Point Food Distribution Center, New} York City. The Food Distribution Center occupies a 329-acre (133-hectare) industrially zoned business park, covering about one third of Hunts Point Peninsula in New York City. It comprises a large concentration of food wholesalers, distributors, and food processing businesses. The major actors include the New York City Terminal Produce Market Cooperative, the Hunts Point Cooperative Market (a meat market), and the Fulton Fish Market (New York State Council on Food Policy, 2009). Each of these markets is among the largest of its kind in the world. The center distributes food locally, nationally, and globally.

Rural Town Food Hub: In this instance the hub is an entire rural town where relationships and strong connections between local food producers, processors, consumers foster a thriving local food economy. A high proportion of local residents are involved in promoting local alternatives to the global food system.

Example: Hardwick, Vermont. With a population of just over 3,000, Hardwick is home to numerous residents attempting to strengthen the local economy by building on the area's historical roots in farming (Hewitt, 2010). They are doing so by returning to local, sustainable agriculture. Many of their food-related business owners, which Hewitt calls "agrepreneurs," share advice, capital, and facilities (Hewitt, 2010). Approximately 100 jobs have been created by these businesses, which include farms, specialty food processors, seed companies, and others. A major local actor is the 
Center for Agricultural Economy. The center uses an entrepreneurial approach to support sustainable agriculture and bring together the community resources and programs needed to develop a locally based, sustainable, healthy, regional food system. The organization conducts strategic planning, provides support services to small food- and agriculture-based business owners and prospective owners, and is establishing a food business incubator.

Hybrid Food Hub: This type of hub is defined by a facility or set of facilities that integrates various kinds of activities described above, making it difficult to identify a specific type. Many existing food hubs function as hybrid food hubs. Eastern Market in Detroit, for example, is self-described as "a local food district with more than 250 independent vendors and merchants processing, wholesaling, and retailing food" (Eastern Market Corporation, 2007). In addition to a Saturday morning farmers' market, Eastern Market also offers processing facilities, wholesale outlets, and a variety of educational programs and food-related services to the community. The market is managed by the Eastern Market Corporation. Another hybrid model is Local Food Hub in Virginia, a communitysupported nonprofit service organization that provides the following services: planning support for growers, networking, refrigeration and freezer storage space rentals, liability and traceability coverage, delivery and consolidation services, and processing (Local Food Hub, n.d.)

\section{Applying Definitions in Practice: An Analysis of Three Food Hubs in Seattle}

The typology above reveals the breadth of formulations about what might constitute a food hub. To gain a more in-depth understanding of the range of food hub possibilities, we conducted a qualitative study of three Seattle sites to illustrate the similarities and differences across food hubs, and to investigate our hypothesis that existing definitions do not sufficiently embrace the wide range of reallife food hubs. Melrose Market, Pike Place Market, and the Chinatown-International District were selected for these case studies because they represent food hubs across our typology's spectrum, and their location in Seattle made them accessible to the authors for in-person observation. The three study areas, identified in figure 1 and described above, are the Chinatown-International District, Pike Place Market, and Melrose Market.

To conduct a consistent assessment of these sites, we developed a checklist-style matrix for on-site observation by a trained researcher. Additional sources of information included websites, city data sources, and personal conversations with stakeholders, such as the storeowners at Melrose Market. The matrix represents an expanded list of the elements defined by the USDA, Wholesome Wave, and de la Salle and Holland, identified in table 1, and of Kloppenberg's 14 sustainable food system attributes. We examined the three food hubs to see how well they fit these approaches, and present summary results in table 2 .

Of the three sites, Pike Place Market best fits each definition. Concordant with the USDA definition, Pike Place offers aggregation facilities and retail opportunities for local producers. As emphasized by Wholesome Wave, Pike Place also offers a wide array of social and human services in connection with its food offerings. Using de la Salle and Holland's approach, Pike Place is characterized by its food-based wholesale and retail outlets, a diverse offering of food-related programming, and urban design and siting that provide transparency and access.

Similarly, The Chinatown-International District includes some of the processing elements highlighted by the USDA, community and social characteristics highlighted by Wholesome Wave, and educational and programming elements mentioned by de la Salle and Holland. Understandably, it lacks the explicit food-related publicprivate partnership that Pike Place Market has due to its geographical scale and history.

The smaller Melrose Market focuses more on retail opportunities and strengthening connections among producers, processors, and consumers, and does not have either the social service elements or the partnerships found in the other two food hubs. 


\section{Figure 1. Three Food Hubs in Seattle, Washington}

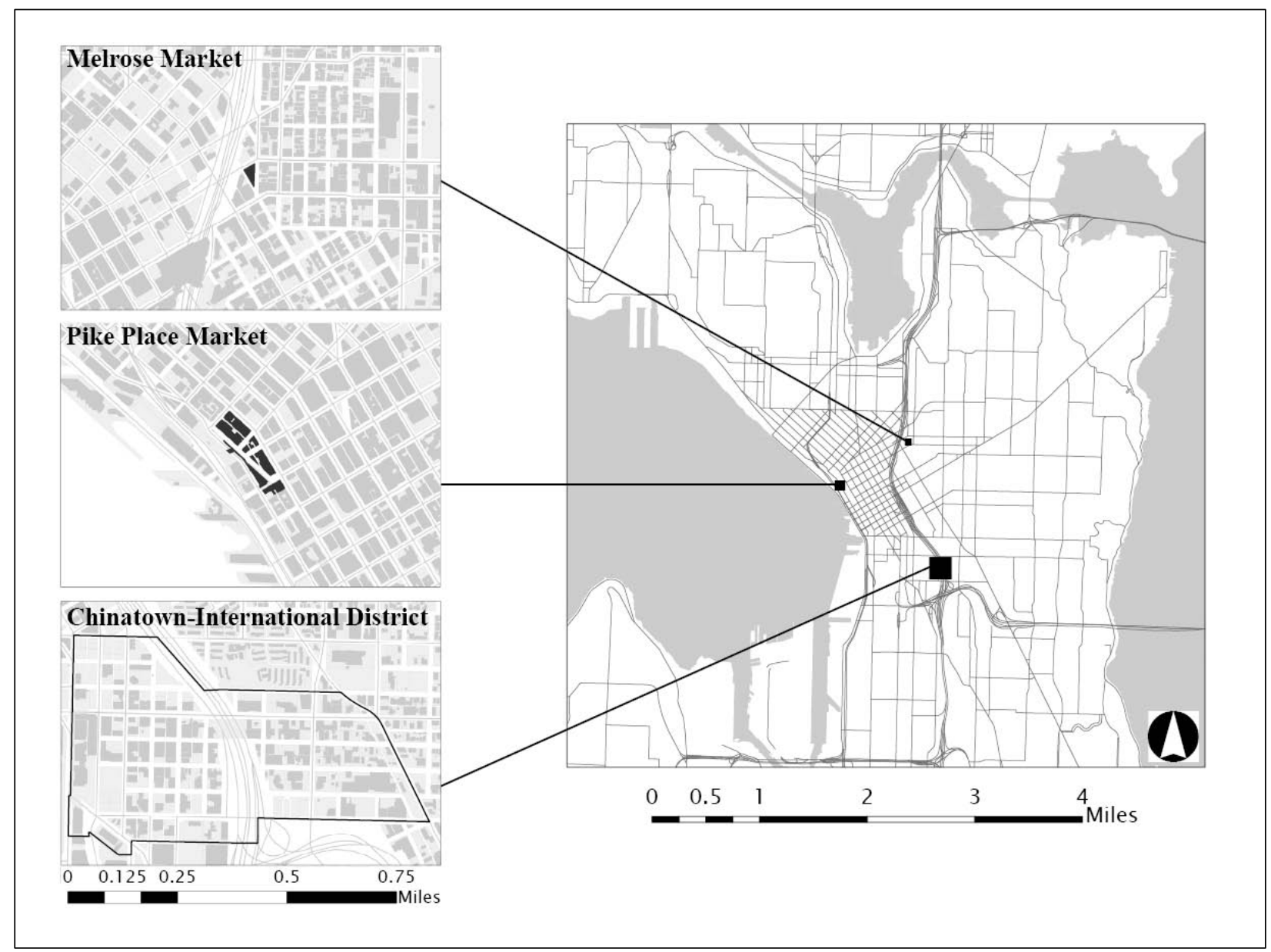

Source: Washington State Geospatial Data Archive. (2011). Retrieved from http://wagda.lib.washington.edu/

These differences do not necessarily indicate a difference in the "success" of the food hub. Rather, these differences may be intentional. We identified five such additional considerations as we looked across our sites: audience, ownership structures, purpose, design, and scale. We will return to these elements below.

In addition to these five new considerations, we found that the strengths, viability, and vitality of each food hub we examined were attributable in part to things not adequately addressed by the definitions in common use. For example, we learned that an important aspect of Melrose Market is the network of relationships fostered among the various food-related businesses that compose the larger facility. Likewise, Chinatown-International District serves an important role as a place for Asian Americans in the greater Seattle area to access affordable and culturally appropriate foods. Pike Place Market, meanwhile, fosters important connections between local residents and tourists to regional producers.

These examples indicate that a more expansive understanding of food hubs, including holistic attributes like Kloppenberg et al.'s (2000), would be useful. Such an understanding of food hubs would enable actors, including urban planners, to consider a wider range of possibilities when developing a food hub or adapting an existing one. For example, a more holistic approach would 
Table 2. Mapping Three Food Hubs to Different Definitions

\begin{tabular}{|c|c|c|c|c|}
\hline \multirow[t]{2}{*}{ Food Hub } & \multicolumn{3}{|c|}{ Food Hub Definitions Met by the Food Hub } & \multirow{2}{*}{$\begin{array}{c}\text { Attributes of a } \\
\text { Sustainable Food System } \\
\text { Kloppenberg et al. }\end{array}$} \\
\hline & USDA & Wholesome Wave & de la Salle and Holland & \\
\hline $\begin{array}{l}\text { Melrose } \\
\text { Market }\end{array}$ & $\begin{array}{l}\text { The provision of } \\
\text { permanent } \\
\text { facilities }\end{array}$ & None & $\begin{array}{l}\text { A diversity of food and } \\
\text { beverage retail, some } \\
\text { processing, architectural } \\
\text { design, and some } \\
\text { programming }\end{array}$ & $\begin{array}{l}\text { Ecologically sustainable, } \\
\text { knowledgeable/communicative, } \\
\text { proximate, economically sus- } \\
\text { taining, sustainably regulated, } \\
\text { healthy, relational, seasonal/ } \\
\text { temporal, and value-oriented } \\
\text { (associative) economies }\end{array}$ \\
\hline $\begin{array}{l}\text { Pike Place } \\
\text { Market }\end{array}$ & $\begin{array}{l}\text { Aggregation and } \\
\text { distribution } \\
\text { facilities and the } \\
\text { provision of } \\
\text { permanent } \\
\text { facilities }\end{array}$ & $\begin{array}{l}\text { Site of multiple } \\
\text { community } \\
\text { services, including } \\
\text { a food bank, } \\
\text { community kitchen } \\
\text { and educational } \\
\text { classes }\end{array}$ & $\begin{array}{l}\text { A diversity of food and } \\
\text { beverage retail, some } \\
\text { processing and storage, } \\
\text { institutions and educa- } \\
\text { tional opportunities, } \\
\text { architectural design } \\
\text { celebrating the public } \\
\text { market, and diverse } \\
\text { programming }\end{array}$ & $\begin{array}{l}\text { Ecologically sustainable, } \\
\text { knowledgeable/communicative, } \\
\text { proximate, economically sus- } \\
\text { taining, participatory, sustain- } \\
\text { ably regulated, healthy, diverse, } \\
\text { relational, seasonal/temporal, } \\
\text { and value-oriented (associative) } \\
\text { economies }\end{array}$ \\
\hline $\begin{array}{l}\text { Chinatown- } \\
\text { International } \\
\text { District }\end{array}$ & $\begin{array}{l}\text { Aggregation and } \\
\text { distribution } \\
\text { facilities }\end{array}$ & $\begin{array}{l}\text { Site of multiple } \\
\text { community } \\
\text { services, including } \\
\text { grocery stores (with } \\
\text { EBT access but not } \\
\text { community-owned) } \\
\text { and a food bank }\end{array}$ & $\begin{array}{l}\text { A diversity of food and } \\
\text { beverage retail, process- } \\
\text { ing and storage facilities, } \\
\text { institutions and educa- } \\
\text { tional opportunities, } \\
\text { architectural design } \\
\text { celebrating the cultural } \\
\text { neighborhood attributes, } \\
\text { and some programming }\end{array}$ & $\begin{array}{l}\text { Ecologically sustainable, } \\
\text { knowledgeable/communicative, } \\
\text { proximate, economically sus- } \\
\text { taining, participatory, sustain- } \\
\text { ably regulated, just/ethical, } \\
\text { sacred, healthy, diverse, rela- } \\
\text { tional, culturally nourishing, } \\
\text { seasonal/temporal, and value- } \\
\text { oriented (associative) } \\
\text { economies }\end{array}$ \\
\hline
\end{tabular}

encourage food hub developers to consider access by low-income residents in addition to the promotion of artisanal foods.

This larger framing would highlight important attributes that have not received attention in the discussion to date about food hubs. One is the relational nature of food hubs. Food hubs can actively coordinate food supply chain activities through a central business management system, as suggested by the USDA. However, there are other, more informal ways of building relationships and networks. For example, at Melrose Market, proximity, shared common space, and a sense of unified purpose help independent storeowners develop relationships based on reciprocity. One of the market's restaurants buys its bread from the neighboring baker and features wine from the wine store. These sorts of relationships may be defining characteristics of food hubs.
Other attributes worthy of more attention in food hub discussions are "seasonal/temporal" and "proximate." These attributes are emphasized both at Pike Place Market and Melrose Market, through the intentional support of local farms and promotion of seasonal and locally produced foods through signage and featuring them in menus. The "just/ethical" attribute deserves more exploration in its relation to food hubs and their development and evolution. Emphasized by Wholesome Wave, but only superficially mentioned by de la Salle and Holland or the USDA, is the notion that a food hub can promote spatial and economic access for people from all socioeconomic and cultural backgrounds to food and food-related health and social services. Food hubs can also actively facilitate the use of food assistance, including SNAP and WIC. 


\section{Considerations for Decision-Making}

Each definition contains a set of organizational and physical considerations. These considerations are important to the initial design or modification of a food hub. In terms of organizational considerations, there are many possible audiences, ownership structures, and purposes for food hubs. Design and scale are important physical considerations. Planners and other actors can ensure that decisions about the organizational structure and physical form consider the community's assets, needs, goals, and expected outcomes of the project.

\section{Audience}

Food hubs attract diverse audiences. The target clientele, whether neighborhood residents, tourists, low-income families, or large-scale food distributors, largely determines the type of food hub. A wholesale-oriented food hub, for example, clusters farmers and food processors so that wholesale food purchasers, such as schools or grocery stores, can purchase food from multiple sources at the same time. A retail-oriented food hub such as a consumers' cooperative serves residents of a city or neighborhood, as would a local market or grocery store.

At Pike Place Market, farm stands and specialty food stores sell to both residents and tourists alike. Melrose Market, meanwhile, attracts a specific, affluent customer base. Most of the stores feature higher-priced local and artisanal foods and some offer fee-based educational opportunities like wine tastings that appeal to their customers.

In addition to specialty foods and products that appear at boutique/ethnic/artisanal food hubs, an important consideration is spatial and economic access for low-income and food-insecure populations. Some food hubs promote access to both retail food outlets and food-related services and programming, such as nutrition classes and food banks. Growing Power, mentioned above, is one food hub that explicitly focuses on providing services and employment and training opportunities to low-income populations. Of the Seattle sites, the Chinatown-International District includes a food bank, community garden, and numerous
WIC and EBT-accepting retailers. Pike Place Market offers subsidized housing, a health clinic, and a food bank.

\section{Ownership}

As detailed by the USDA, food hubs have various ownership models, including nonprofit, producer/ entrepreneur, public sector, and consumer-driven. When there is a single owner, it is often easier to establish a shared identity using strategies such as common marketing and signage. However, certain types of food hubs may exist and function without an identified leader, as in the case of the Chinatown-International District, a neighborhoodbased food hub with multiple independently owned businesses but without a single guiding entity or manager. The closest proxies may be the business improvement association (which only covers half the area), the city of Seattle through its neighborhood planning process, or the design and development guidance required through its International Special Review District and National Historic Register District status — none of which specifically addresses food issues at this time.

\section{Purpose}

The purpose, or more likely purposes, of each food hub vary depending on ownership, market feasibility, and other considerations. In the case of the destination food hub Pike Place Market, the dominant purposes are tourism, place-making, and retail sales. The market is a major destination in downtown Seattle, providing a place for tourists to visit and locals to shop. For this reason, the Pike Place Market Preservation \& Development Authority calls Pike Place the "soul of the city" (Pike Place Market Preservation Authority, 2010). In addition to the food-related businesses, Pike Place Market also hosts numerous specialty shops and street performers and works actively to maintain its historic character.

Melrose Market, on the other hand, was explicitly established as a profit-making venture. Secondary purposes include reusing historic buildings, demonstrating connections between local producers and a food-oriented public, and providing 
opportunities for small start-up and independent food businesses.

In the Chinatown-International District, there is less of a shared purpose, as the food hub comprises multiple independent retailers without a common manager, spread across numerous city blocks. However, a common identity comes from the area's unique historical and cultural character. Chinatown-International District is also a tourist destination that includes some of the city's best Asian restaurants and specialty food markets.

There are more purposes, of course, than we found in our cases. One of the more forward-thinking ideas is that food hubs can be models for foodrelated sustainability efforts, including rooftop gardens, on-site composting, food reclamation, and waste reduction. The housing of Portland's food hub by the organization EcoTrust is an example of these connections.

\section{Design and Siting}

Design is the means of tying together the purpose and processes of a food hub into a corresponding form. An important contribution of the de la Salle and Holland definition is their emphasis on the design elements of a food hub. Design and siting are also important aspects of the three Seattle food hubs.

Pike Place Market, for example, comprises a number of buildings constructed specifically for the purpose of hosting farm stands and numerous small businesses. Its open walkways encourage passersby and its concrete floors facilitate easy cleanup after busy market days. Meanwhile, it features numerous unique design elements, including a historic neon sign declaring "Public Market" that distinguishes it from the surrounding areas. Melrose Market, meanwhile, contains design elements related to the building's former use as an auto dealership. The designers adapted existing elements to make the space function as a food hub. For example, the market's triangular building was subdivided into small spaces for lease by small businesses.
De la Salle and Holland's definition is the only one we found that focuses on the physical setting and design characteristics of a food hub. We appreciate this, but call for more than their focus on agricultural architecture. Food hub design would be better served by an architectural design that is contextually appropriate and that allows for the rhythms of the food system's physical and social processes to occur as effortlessly as possible.

In terms of siting, food hubs can be located in rural areas, suburbs, urban villages, near transportation hubs including ports, in central business districts, and in residential neighborhoods. Siting is an important consideration that differs according to the context, but in general, a food hub needs to be accessible by its various potential users via multiple forms of transportation. For example, farmers and distributors may need truck access and parking, while local residents benefit from access by walking, biking, transit, and personal automobile. Siting may also offer opportunities for direct connection to food production, such as community gardens, rooftop gardens, and working farms.

One challenge to design and siting is that food hubs, as we have demonstrated, are not all alike. Some operate from one centrally managed facility or set of facilities, while others consist of independent structures without clear programmatic relationships. As an example of the latter, the Chinatown-International District is a historic district and a mixed-use urban neighborhood that has developed over time. Thus, the architectural and design details are historical and cultural, and the food hub characteristics observed in the area are circumstantial, not intentional. For example, many windows invite passersby to view live crabs and roasting ducks, while neon signs promote restaurant offerings. Yet these items are marketing features that predate the design concerns of agricultural urbanism and its related design features. Furthermore, while the district exhibits strong elements that visually distinguish the hub or precinct from surrounding areas, the majority of these features relate to the district's cultural identity (such as the Chinatown Gate) rather than foodspecific items. Instead of agricultural architecture, 
then, we prefer appropriate architecture for the local context that provides food hub-related benefits.

Scale

Scale affects the retail and wholesale mix and range of components of a food hub. There are different geographic scales of food hubs, from a single building to an entire neighborhood district. A small facility such as Melrose Market may be home to a handful of retail and wholesale establishments, while large-scale hubs such as ChinatownInternational District and Pike Place Market may be home to hundreds. Size also determines the range of components that can be included in a food hub. For example, Chinatown-International District encompasses a food-producing garden on a large hillside within the neighborhood, something that is difficult to plan for within a smaller-scale hub.

More than the other two areas we have explored, Melrose Market suggests that there is a relationship between the size of a food hub and the choices it must make among a range of possible features and functions. Melrose Market does not exhibit whole-

Table 3. Important Food Hub Considerations: Audience, Ownership and Purpose, Design and Siting, and Scale

\begin{tabular}{|c|c|c|c|}
\hline Type & Boutique/ Ethnic/Artisanal & Destination Food Hub & Neighborhood-Based Food Hub \\
\hline Example & Melrose Market, Seattle & Pike Place Market, Seattle & $\begin{array}{l}\text { Chinatown-International District, } \\
\text { Seattle }\end{array}$ \\
\hline Audience & $\begin{array}{l}\text { Generally higher-income } \\
\text { consumers with a preference for } \\
\text { artisanal and specialty foods. }\end{array}$ & $\begin{array}{l}\text { Tourists and residents of all } \\
\text { economic backgrounds, with a } \\
\text { focus on those seeking locally } \\
\text { produced foods. }\end{array}$ & $\begin{array}{l}\text { Asian American community, } \\
\text { businesspeople, local residents, } \\
\text { and tourists. }\end{array}$ \\
\hline Ownership & Melrose Project, LLC & $\begin{array}{l}\text { Pike Place Market Preservation } \\
\text { and Development Authority } \\
\text { (PDA), a public development } \\
\text { entity established under } \\
\text { Washington State law }\end{array}$ & $\begin{array}{l}\text { No single entity; multiple } \\
\text { independent business owners. } \\
\text { Some collective coordination by } \\
\text { Business Improvement } \\
\text { Association and by city of Seattle }\end{array}$ \\
\hline Purpose & $\begin{array}{l}\text { For-profit. Reuse historic } \\
\text { buildings, create opportunities } \\
\text { for small businesses, sell } \\
\text { artisanal and local foods. }\end{array}$ & $\begin{array}{l}\text { Its charter requires the PDA to } \\
\text { preserve, rehabilitate and } \\
\text { protect the market's buildings; } \\
\text { increase opportunities for farm } \\
\text { and food retailing in the market; } \\
\text { incubate and support small and } \\
\text { marginal businesses; and } \\
\text { provide services for low-income } \\
\text { people. Also serves as a major } \\
\text { tourist attraction. }\end{array}$ & $\begin{array}{l}\text { Independent businesses are for } \\
\text { profit. The mission of the } \\
\text { Business Improvement } \\
\text { Association is to promote } \\
\text { economic vitality of the district, } \\
\text { encourage responsible business } \\
\text { development, and support } \\
\text { continuous improvement of the } \\
\text { quality of life in the district for its } \\
\text { business owners, residents, and } \\
\text { visitors. Serves as a cultural hub. }\end{array}$ \\
\hline $\begin{array}{l}\text { Design } \\
\text { and Siting }\end{array}$ & $\begin{array}{l}\text { Adaptive re-use of historic } \\
\text { buildings. Located in dense } \\
\text { urban neighborhood near } \\
\text { downtown Seattle. }\end{array}$ & $\begin{array}{l}\text { The market, comprising eight } \\
\text { buildings and covering nine } \\
\text { acres ( } 4 \text { hectares) in downtown } \\
\text { Seattle near the waterfront, } \\
\text { contains the Market Historic } \\
\text { District. Includes some } \\
\text { identifying historic signage. }\end{array}$ & $\begin{array}{l}\text { Urban, federally recognized } \\
\text { historic neighborhood. Cultural } \\
\text { center for Asian Americans in } \\
\text { region. Characterized by design } \\
\text { elements like red dragons and } \\
\text { lampposts. }\end{array}$ \\
\hline Scale & $\begin{array}{l}\text { One city block. Includes two } \\
\text { refurbished buildings. Home to } \\
\text { seven food-related businesses } \\
\text { (of nine total) and a common } \\
\text { atrium. }\end{array}$ & $\begin{array}{l}\text { Home to more than } 200 \text { year- } \\
\text { round commercial businesses; } \\
190 \text { craftspeople; approximately } \\
100 \text { farmers who rent table } \\
\text { space by the day; } 240 \text { street } \\
\text { performers and musicians; and } \\
\text { more than } 300 \text { apartment units. }\end{array}$ & $\begin{array}{l}\text { Mixed-use, dense urban } \\
\text { neighborhood. Over } 130 \\
\text { independent food businesses } \\
\text { located in a ten-block radius, } \\
\text { including several food processors } \\
\text { and wholesale markets. }\end{array}$ \\
\hline
\end{tabular}


sale, storage, governmental services and institutions, production gardens, or educational opportunities. This is at least in part attributable to its smaller size and the fact that it was a redevelopment project in an expensive urban area, necessitating higher returns. Table 3 summarizes these considerations, demonstrating how organizational and physical considerations play an important role in shaping food hubs.

\section{Role of Planners}

Planners, particularly those involved in food system planning, transportation, economic development, and neighborhood planning, should become familiar with food hubs given the various important roles and opportunities they present. Particularly as cities and regions seek to "relocalize" their food systems, these tools will need to be considered more frequently and rigorously. In the course of assisting communities to create or enhance food hubs, planners can help others involved understand the broad range of potential food hubs. They can assist in matching existing community needs and assets to the type of food hub most likely to achieve desired outcomes. The role of planners is increasingly critical as more and more municipalities engage in food hub development through policy-making, planning, program development, and/or partnerships.

In Washington state, the Port of Columbia is developing Blue Mountain Station, the "world's very first destination eco-food processing park dedicated to the recruitment and marketing of artisan food processors, primarily in the natural and organic sectors" (Blue Mountain Station, n.d.). In the city of Everett, county and municipal officials have collaborated with the local farmers' cooperative and a private developer to construct the city's first indoor, year-round farmers' market. Part of a mixed-use development featuring affordable housing, the 60,000-square-foot agriculture center will serve as a distribution hub, processing facility, and retail outlet. But Washington is by no means alone in these efforts; the National Good Food Network continually provides new examples of food hub development all over the United States on its website.
Perhaps most importantly, planners can help clarify how foods hubs fit within the broader context of a sustainable food system and establish linkages among demographics, land use, transportation, and economic development. This would help ensure appropriate infrastructural choices for given places. For example, planners can help stakeholders consider the transportation, distribution, and freight infrastructure needs for a particular food hub location or type. They can identify zoning barriers and suggest creative solutions. Planners also can leverage relationships with policy-makers, local business and neighborhood associations, and food systems stakeholders to ensure that planning for and evaluating foods hubs incorporate the voices and participation of diverse viewpoints. They can also bring together knowledge of different funding sources, grant programs, economic development agencies and public development authorities, and incentive packages that can be used to develop a successful food hub as part of a sustainable regional food system.

Planners can also play a coordinating role with stakeholders to adapt existing food hubs or develop new ones, and they can support networks of food hubs. Coordination might ensure that actors fully consider decision-making characteristics that relate to both processes of implementation and development of physical forms. This could include managing expectations and possible nuisances coming from the development of unfamiliar structures like food hubs. Planning for integrated networks of regional food hubs is a natural outgrowth of relocalization strategies. The Regional Food Hub Advisory Council of California identified ways that a regional food network can support and strengthen the operations of individual food hubs. These include facilitating interhub brokerage, tapping into existing infrastructure, and providing logistics services. In addition these key functions, other services and support include cost sharing, fundraising, training, and networking. Planners, who have skills in cross-sector thinking, assessment and analysis, and stakeholder engagement, would be natural members of this kind of coordinating body. 


\section{Conclusion}

This paper provides a background for existing definitions of food hubs and provides a new typology for better conceptual understanding. The timing is especially relevant, as the USDA intends to refine its working definition of food hubs (USDA, 2011). Honing the typology and refining the list of components and attributes will be helpful in establishing a useful and comprehensive definition.

Future research can also complement the current effort by the USDA and by the National Good Food Network, which involves focus groups and surveys, to develop a greater understanding of the scope and scale of existing food hub operations and their challenges and opportunities for growth. Other avenues for research include in-depth case studies of specific food hubs. Case studies could analyze the actors and motivations involved, development processes, and outcomes in both the local food system and local communities. One area of emphasis could be comparing intentionally planned food hubs with unplanned ones.

We recognize that there are important reasons for using a limited definition of food hubs, especially when guiding an organization's work. At the same time, we believe there is value in embracing a more comprehensive definition. Clearly, it will be a challenge to establish a definition that adequately addresses all the functions, purposes, attributes, and types of food hubs. Further, there is danger in developing the definition too much and thereby rendering it useless for focused application. A good definition will be broad enough to encapsulate the varying characteristics of most cases, but not so broad that any food enterprise could be called a food hub. We offer the following definition:

A food hub serves as a coordinating intermediary between regional producers and suppliers and customers, including institutions, food service firms, retail outlets, and end consumers. Food hubs embrace a spectrum of functions, purposes, organizational structures, and types, each of which can be tailored to achieve specific community-established objectives. Services provided by a food hub may include and are not limited to aggregation, warehousing, shared processing, coordinated distribution, wholesale and retail sales, and food waste management. Food hubs contribute to strengthening local and regional food systems as well as to broader community goals of sustainability and health.

Clearly, the conversation regarding food systems and food hubs is evolving and will continue to grow in significance.

\section{References}

Barham, J. (2010, December 14). Getting to scale with regional food hubs [Blog post]. Retrieved from http://kyf.blogs.usda.gov/2010/12/14/getting-toscale-with-regional-food-hubs/

Blue Mountain Station. (n.d.). Why a food park? Why organic? Retrieved from http://www.blue mountainstation.com/about/why/

The Center for an Agricultural Economy. (n.d.). Retrieved from http://hardwickagriculture.org/

Connell, D. J., Smithers, J., \& Joseph, A. (2008). Farmers' markets and the "good food" value chain: A preliminary study. Local Environment, 13(3), 169185. http://dx.doi.org/10.1080/1354983070166909

De la Salle, J., \& Holland, M. (2010). Agricultural urbanism: Handbook for building sustainable food and agriculture systems in 21st century cities. Vancouver, BC: HB Lanarc.

Eastern Market Corporation. (2007). Detroit Eastern Market. Retrieved from http://www.detroiteasternmarket.com/

Ecotrust. (2011). About Food Hub. Retrieved from http://food-hub.org/

FamilyFarmed.org. (2010). Ready to grow: A plan for increasing Illinois fruit and vegetable production. Retrieved from http://ngfn.org/resources/ngfndatabase/knowledge/IllinoisProduceReportfinal.pdf

FamilyFarmed.org and Wallace Center. (2010). Local food system assessment for northern Virginia. Retrieved from http://www.wallacecenter.org/ourwork/Resource-Library/wallacepublications/Northern-VA-LFS-Assessment-FinalReport.pdf 
Gerencer, M. (2011). Healthy food purchasing: Farms to schools, cities, hospitals, jails, and other institutions.

Presentation at Communities Putting Prevention to Work Coalition Meeting, King County, Washington, April 26, 2011.

Growing Power, Inc. (n.d.). About us. Retrieved from http://www.growingpower.org/

Hewitt, B. (2010). The town than food saved: How one community found vitality in local food. Emmaus, Pennsylvania: Rodale Books.

Homegrown Sustainable Sandwich Shop. (n.d.). Theory. Retrieved from http://www.eathomegrown.com/theory

Kallus, R., \& Law-Yone, H. (2000). What is a neighbourhood? The structure and function of an idea. Environment and Planning B: Planning and Design, 27, 815-826. http://dx.doi.orgh/10.1068/b2636

Kloppenberg, Jr., J. K., Lezberg, S., Master, K. D., \& Stevenson, G. W. (2000, Summer). Tasting food, tasting sustainability: Defining the attributes of an alternative food system with competent, ordinary people. Human Organization, 59(2), 177-186.

Local Food Hub. (n.d.). How we work with buyers. Retrieved from http://localfoodhub.org/ourfood/how-we-work-with-buyers/

Morley, A., Morgan, S., \& Morgan, K. (2008). Food hubs: The "missing middle" of the local food infrastructure? BRASS Centre, Cardiff University. Retrieved from http://www.ngfn.org/resources/ ngfn-database/knowledge/Food Hub KM0908.pdf/view

National Good Food Network. (2011). Regional food hubs: Linking producers to new markets. Retrieved from http://www.ngfn.org/resources/ngfndatabase/knowledge/RFHub\%20Presentation complete $\% 20$ version 5.24.pdf/view

New York State Council on Food Policy. (2009). Hunts Point Terminal Produce Market. Retrieved from http://www.nyscfp.org/.../Hunts Point Terminal Produce Market-Madelyn Wils.pdf
Occidental College Urban and Environmental Policy Institute. (n.d.) Regional food hub and regional food hub network. Retrieved October 30, 2011, from http://departments.oxy.edu/uepi/cfj/rfh.htm

Pike Place Market Preservation Authority. (2003). Charter. Retrieved from http://www.pikeplace market.org/market organizations/pda council committees

Pike Place Market Preservation Authority. (2010). History of Pike Place Market. Retrieved from http://www.pikeplacemarket.org/visitor info/ market history

PCC Natural Markets. (n.d.). About PCC. Retrieved from http://www.pccnaturalmarkets.com/about/

Puget Sound Food Network. (n.d.). Retrieved from http://www.psfn.org/

Regional Food Hub Advisory Council. (2010). A California network of regional food hubs: A vision statement and a strategic implementation plan. Retrieved from http://www.ams.usda.gov/AMS v1.0/getfile?dDocName=STELPRDC5091490

Smith, D. (2011, January 8). Year-round public market set for Everett. The Herald Net. Retrieved from http://www.heraldnet.com/article/20110108/ NEWS01/701089940

United States Department of Agriculture (USDA), Agriculture Marketing Service (AMS). (2011). Regional food hubs: Understanding the scope and scale of food hub operations (PowerPoint slides). Retrieved from http://www.ams.usda.gov/AMS v1.0/getfile?dDocName=STELPRDC5090409

Wholesome Wave. (n.d.). Healthy food commerce initiative. Retrieved from http://wholesomewave.org/hfci/

Wholesome Wave. (2010). The food hub. Retrieved from www.safsf.org/documents/ FoodHubResearch Present 101210.pdf 